\title{
What is Spatial About Right-Wing Discourses?
}

\author{
Karin Golser and Thomas Jekel \\ University of Salzburg, Austria
}

\begin{abstract}
In recent times, right-wing parties and movements have increasingly been using (geoIsocial media to communicate their political aims. Examples are the 'Einzelfall-Map' or earlier maps that were designed to show refugee infrastructure but doubled for use in planning attacks on refugees. A closer inspection of these maps shows the use of simplified and generalized language, disrespect for the rule of law and human rights, and xenophobic metaphorical language.

While these characteristics are used not only by right-wing movements (they can also be identified in left-wing anti-globalization discourse), right-wing movements tend to use spatial language more often than other political tendencies. This paper analyses language used by rightwing populists in maps that are based on volunteered geographic information - as for example in the 'Einzelfall-Map'. The analysis of the contents of the map, based on the 'syndrome approach', presents the various discourses that circulate around the topic 'right-wing populism'.

This analysis contributes to the development of teaching strategies that unearth the explicitly geographic language used by populist ideologies.
\end{abstract}

\section{Keywords:}

right-wing extremism, geomedia, VGI, education

\section{Introduction}

Right-wing movements tend to use social-media fora to communicate their political aims and to recruit their followers. Social media could be described as a terrain where much is played out politically. It can be argued that there is a transfer of political activism from public to virtual space (Jekel, Lehner \& Vogler, 2017, p. 14). Web 2.0 enables the sharing of usergenerated content, and as a result there are quite a few forms of collaboration and interaction between users/followers and content producers. Right-wing populism is also spread through the medium of maps. The main aim of this paper is to analyse how xenophobic and spatial language is spread in (geo-)social media. For this analysis, the function(s) of the so-called 'Einzelfall-Map' and some of the comments of the community of authors contributing to the 
map will be discussed. The 'Einzelfall-Map' is an online-map by rightwing extremist activists that is based on volunteered geographic content on alleged crimes committed by foreigners. Before we can focus on the 'Einzelfall-Map' itself, a few theoretical foundations are needed. First, therefore, we discuss the meaning of right-wing extremism and its ideology before giving a short introduction to the 'Einzelfall-Map'. A qualitative analysis of the map is then presented in order to be able to deconstruct its contents, allowing the basic ideas of the syndrome approach to be explained. Finally, consequences and strategies for secondary education are presented.

\section{Right-wing extremism}

Populism is not a new phenomenon; for centuries it has been a distinct method of mobilization used by a variety of parties. Nowadays, right-wing populism in particular is disseminated by a wide range of different channels. Its ideology is quite incoherent: '[R]rightwing parties propose a mixed bag of beliefs, stereotypes, attitudes and related programs which aim to address and mobilize a range of equally contradictory segments of the electorate' (Fuchs, 2016, p. 173). In this paper, we follow the definition of 'ideology' proposed by Fuchs: 'thoughts, practices, ideas, words, concepts, phrases, sentences, texts, belief systems, meanings, representations, artifacts, institutions, systems or combinations thereof that present and justify one's group's or individual's power, domination or exploitation of other groups or individuals misrepresenting, one-dimensionally presenting or distorting reality in symbolic representations' (ibid.). This comprehensive definition also seems to be appropriate for right-wing ideologies.

Right-wing populists use different means to spread their ideology in a 'convincing' way. One is the extensive use of the media, for example the press and TV, but also new geo-social media like Facebook and Twitter. Right-wing populists are well-trained media personalities. Their goal is to present a personality that is very different from the 'slick' mainstream political appearance; they represent themselves as the saviours of the 'man and woman in the street' (Wodak, 2013).

Their programmes are aggressive and exclusionary and are based on a generalized and salient claim to represent 'THE (homogeneous) people' (Wodak, 2013). Pelinka (2013, p. 7) argues that '[A] any kind of populism directed against an ethnically and/or nationally and/or religiously defined "other" can be seen as "right wing". So, this is possibly one of the most popular strategies to generate ideology: 'us', the in-group, against 'them', the out-group. VAN Houtum and van Naerssen (2002) describe the building of 'in-groups' and 'out-groups' as a three-step process: the first step is bordering, the second is ordering, and the final one is othering. '[B]ordering rejects as well as erects othering' (van Houtum \& van Naerssen, 2002, p. 126). On the one hand, bordering processes tend to level territorial ambiguity and ambivalent identities. On the other hand, this causes the creation of new differences or 'reproduce[s] latently existing differences in space and identity' (van Houtum \& van Naerssen, 2002, p. 126). This claiming of a unity out of different cultures, a so called 'subculture', produces groups which are (voluntarily) assimilated, and others which are marginalized (van Houtum \& van Naerssen, 2002). Currently, in the political discourse of the 
public sphere in many European countries, a normalization of, or even explicit, 'othering' can be identified, and this is 'occurring at all levels of society, ranging from the media, political parties and institutions to everyday life interactions' (Wodak, 2013, p. 26).

The greatest risk of this designation of 'us' and 'them' is to generate profound denial and hatred. In general, populism tends to simplify complex developments by looking for a culprit (Pelinka, 2013), a process caused by various factors. These might be problems experienced by national citizens, like unemployment or poverty, or during a general economic crisis, which could strengthen right-wing movements. Often the locals, the 'in-group', are 'afraid' that the problems will be aggravated by the 'out-group' (Alvares \& Dahlgren, 2016).

Recently, right-wing populism has successfully been constructed as a 'social dilemma' - the immigration of refugees. Through refugee movements, a xenophobic mood has come to the fore, and 'nationalistic, ethnic, racial overtones' (Alvares \& Dahlgren, 2016, p. 47) are used against 'foreigners', who attract a negative attitude among the 'in-group'. In summary, it should be noted that right-wing populism sees multiculturalism as a considerable threat and its goal is to construct ethno-national purity. And as long as there is a tendency to believe in (non-existent) homogeneity, there will be enough energy for people to defend their own values against the 'out group' (Pelinka, 2013, p. 8).

Many of the phenomena described above also use different semantic categories, for example negative metaphors, hyperboles, generalizations or dehumanizing terms to refer to foreigners, and several other topoi (or argumentative schemes; see 4.2 below) that are very close to how the syndrome approach defines right-wing extremism (Holzer, 1994; see 4.3 below). These elements of extremist discourses fitting into right-wing populism and surfacing in public fora are alarming and require an educational response.

\section{The case of the 'Einzelfall Map'}

Another method to spread right-wing ideas is the combination of texts with illustrations, for example posters or maps. Mapping right-wing movements (or their effects in social space) has some tradition in geography and geography education. In their discussion of students' mapping of migrants' histories in Seattle (histories clearly influenced by right-wing and xenophobic suppression), Gordon, Elwood \& Mitchell (2016) (see also Elwood \& Mitchell, 2013) show that political formation of the subject can be fostered through collaborative mapping and the generation of volunteered geographic information. Along similar lines is a mapping project that plots on a map the current use of Nazi symbols - the \#notmysymbol initiative (Jekel, Lehner \& Vogler, 2017). It was here that the idea of looking into virtual landscapes for right-wing spatial language was developed, as the Neo-Nazi community seems to have retreated (or diversified) from public spaces into social media, providing their alternative worldview based on alternative facts to their community and beyond.

A host of initiatives have also centrally or as a side issue analysed Volunteered Geographic Information content. FloatingSheep (www.floatingsheep.org) provides a host of maps linking data from various social media platforms, but mainly Twitter. Research here examines mostly specific terms to identify geographies of hate and racism (among other things). 
Beyond visualization, Pokraka et al (2016) delved into a critical analysis of the 'Braune Karte' ('brown map') with the explicit aim of deconstructing cartographically-supported ideologies in educational settings. At the same time, FUCHS (2016) analysed rightwing language in social media during the 2016 Austrian presidential election campaign. However, none of these contributions looked into the explicitly spatial language of social media content. The analysis of the 'Einzelfall-Map' here provides some initial ideas to help structure this domain.

The 'Einzelfall-Map' (Einzelfall-Map, 2016) is one example of how lay people use a popular geographic medium, like Google Maps, to spread their right-wing populist ideas. The greatest danger is that the information presented could be understood as an absolute truth. The basis of the map is a mixed bag of recent news stories; their lowest common denominator is to promote a racial overtone in order to attack a special group, namely immigrants. The exact goal of this map is to show how often immigrants are (supposedly) involved in criminal cases or in other forbidden or reprehensible activities. This map is constructed by five individuals, one man and four women, who hide their identities for 'security reasons' (Krautkrämer, 2016). The Junge Freibeit (JF), a newspaper with right-wing populist tendencies, presented an interview with one of the founders that gives evidence of the initiator's right-wing populist background (Krautkrämer, 2016).

The map shows about 10,000 'Einzelfälle' (individual criminal offences) in Germany and Austria (2016) which were allegedly committed by immigrants. Some of them are documented by the police, but there are other sources as well, for example newspaper articles, without certified information. In addition, it has to be noted that there is no evidence for alleged 'criminal offences', and no court sentences (Der Standard, 2017).

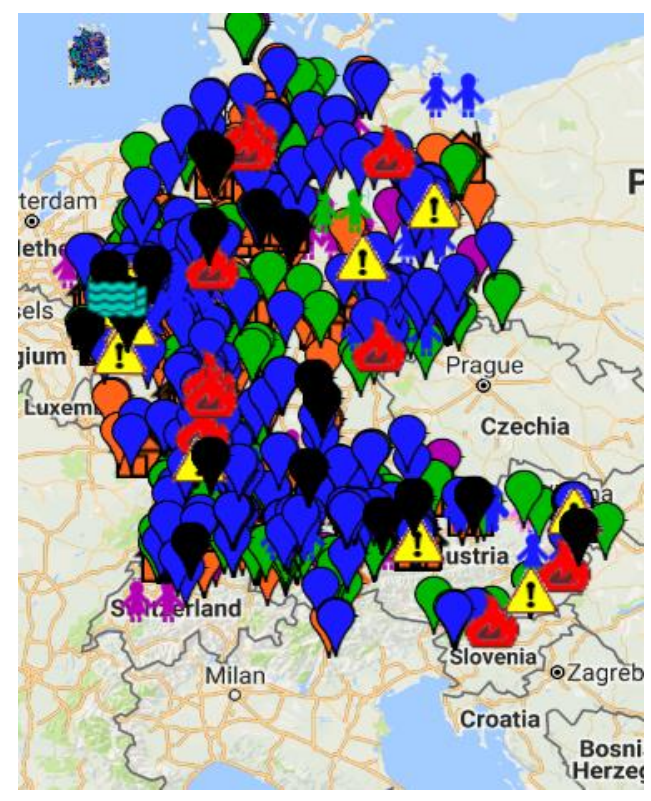

Figure 1: Einzelfall-Map, 2016 ,

https://www.google.com/maps/d/viewer?mid=1 rNT3k2ZXB-f9z-

2nSFMIBQKXCs\&hl=en US\& $\|=60.6325623185327 \% 2 C 20.043452102246192 \& z=6,01.06 .2017$. 
If we look more closely at the map (Figure 1), the majority of the alleged crimes can be quickly disproved. The city of Cologne provides a suitable example. Cologne is the largest city in North Rhine-Westphalia, the federal state with the highest rate of asylum applications in Germany (Statista, 2016). As a 'logical' consequence, if we follow the arguments of the authors of 'Einzelfall-Map' map, there should be a very high occurrence of crimes in the city.

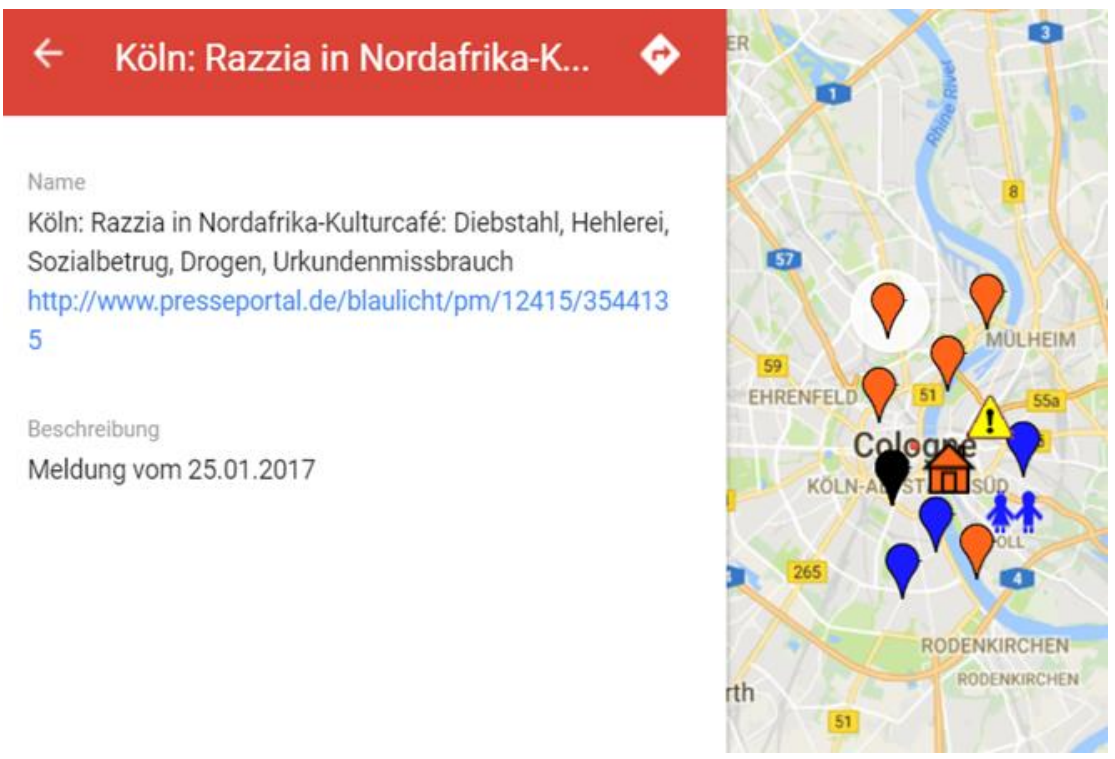

Figure 2: Einzelfall-Map Köln,

https://www.google.com/maps/d/viewer?mid=1 rNT3k2ZXB-f9z-

2nSFMIBQKXCs\&hl=en US\& $\|=56.74999999999998 \% 2 C 16 \& z=18,01.06 .2017$.

However, there are only twelve crimes recorded for Cologne city centre. Much of the effect of the 'Einzelfall-Map' can therefore be traced to the effects of the visualization, which appears dense if one is looking at the whole map.

One entry of the 'Einzelfall-Map' will serve to give an impression of the contributors' work:

'Köln (06.01.2017): Razzia in Nordafrika-Kulturcafé: Diebstabl, Heblerei, Sozialbetrug,

Drogen, Urkundenmissbrauch' (Einzelfall-Map Köln, 2017)

Cologne: raid in North African cultural café: theft, stolen goods, social fraud, drugs, misuse of documents. (authors' translation)

\section{A qualitative analysis of the 'Einzelfall-Map'}

In this section, we relate content of the 'Einzelfall-Map' to semantic categories, topoi and 'principles' that have been used to identify right-wing extremism. 


\section{Semantic Categories}

Zapata-Barrero \& Rubio-Carbonero (2014) identify four semantic categories which are used as headliners in political and social discourses to incite hatred:

\section{Use of negative generalizations:}

The use of negative generalizations is one of the most typical discriminatory resources. A negative behaviour or attitude of an individual is presented as being typical of the whole social group. It is also a kind of simplification that does not consider exceptions. Both negative generalizations and simplification are the 'base' for creating stereotypes and prejudices.

\section{Use of negative hyperboles:}

Negative hyperboles are when generalizations are dramatized and exaggerated. They are regularly part of political discourse, as is often the case in the discussion of migration - for instance, when in a given political situation political leaders argue that the massive arrival of refugees is provoking a national crisis or might lead to civil war (Zapata-Barrero \& RubioCarbonero, 2014, p. 61)

\section{Use of negative metaphors:}

In general, metaphors are used to describe objects and subjects - for example the behaviour of people. A well-prepared metaphor may create a different reality. 'Metaphors have a great power to conceptualize abstract and complex realities based on concrete experiences that are more familiar and accessible for the audience' (Zapata-Barrero \& Rubio-Carbonero, 2014, p. $58)$.

A metaphor can also influence how reality is understood; very often, some aspects of reality are hidden while others are highlighted. This has emotional impacts and could influence the audience's opinions and attitudes in a negative way. Metaphors are often used in political discourses - especially on immigration topics - to fuel anxiety and fear. Natural disasters like 'waves', 'avalanches' or 'tsunamis' are connected with the arrival of immigrants and explicitly denote spatial contexts (Zapata-Barrero \& Rubio-Carbonero, 2014). A 'naturalized language' is used to fortify political discourses (JEKEL \& HUBER, 2005). Again, negative emotions, for example fear and, consequently, defensiveness, can be found in the local society. In addition, 'in-groups' and 'out-groups' are formed, and local societies or even the populations of entire nations run the risk of polarization and division.

\section{Use of debumanizing terms referring to immigrants:}

Using dehumanizing terms to refer to immigrants means that an objectifying language is utilized. Examples would be describing them collectively as 'illegal', 'criminals', 'dangerous' etc., or describing them as 'animals' or 'beasts'. As a consequence the 'bad image' of immigrants becomes worse (Zapata-Barrero \& Rubio-Carbonero, 2014). 


\section{Topoi}

The four categories above, which are particularly present in the rhetoric of right-wing populism, generate further argumentative instruments that can be used against immigrants. These argumentative strategies are known as topoi, the idea of which goes back to Aristotle, who defined a topos as an 'argumentative scheme, which enables a dialectician or rhetorician to construe an argument for a given conclusion' (Rapp \& Wagner, 2012). In the present context, topoi are based on a 'a supposedly shared belief that is presented in a general way and that, since it appeals to common sense, is established as an unquestionable truth, which does not need to be justified' (Zapata-Barrero \& Rubio-Carbonero, 2014, p. 66). Thus, a topos can be defined as a social belief that depends on values and norms in a concrete context, but it its use is not a reflective process (Zapata-Barrero \& Rubio-Carbonero, 2014).

Topoi which frequently appear in right-wing discourses are, for example, 'threat' or 'burdening'. The implication here is that an actor's issue should always be solved or diminished by taking action against another group. Another group of topoi are the 'topoi of advantage', for example an action that is useful only for one part of a population or even only for a few individuals. The opposite could also happen: an action is useless for a particular group or for certain individuals, and the conclusion is that something has to be done (Zapata-Barrero \& Rubio-Carbonero, 2014).

\section{The syndrome approach}

To analyse and deconstruct the contents of the 'Einzelfall-Map' in an appropriate way, the syndrome approach is used. Holzer (1994) defines the syndrome approach as a bundle of interconnected features which are suited for defining right-wing extremism. This tool requires the identification of different discourse topics, a procedure which accesses some of the semantic features already explained. Overall, five principles are associated with 'rightwing populism/extremism' (Holzer, 1994):

1. the principle of 'nature' or 'naturalness'

2. the principle of 'unvarying characteristics of people'

3. the principle of 'a world system of apartheid'

4. the principle of 'the function of a scapegoat'

5. the principle of 'nationalizing historiography'.

These five principles include many of the semantic categories and topoi discussed above and have informed our classification of the 'Einzelfall-Map' content.

\section{$5 \quad$ Results}

Holzer (1994) first described the principle of 'nature' or 'naturalness'. If a person is already unwanted for ethnic reasons, this principle enables him or her to be judged 'unnatural'. Social and global inequalities and related hierarchies are also legitimized by this principle.

Essen (18.01.2017): Horde augenscheinlicher Orientalen raubt Fabrgast im Bus unter Androhung von Scblägen das Handy - Fotofahndung' (Einzelfall-Map Essen) 
'Essen: A horde of apparent Orientals on a bus robbed a passenger of his smartphone by threatening to beat him - photo search' (authors' translation)

Here it is necessary to examine the etymology of the word 'horde': the word comes from Polish, and it was used in a general sense for a wild and dangerous wandering gang (FINE Dictionary). Furthermore, animals may live in 'hordes'. In addition, in the terminology of Zapata-Barrero \& Rubio-Carbonero (2014), the 'horde' can be classified as a dehumanizing term.

Here is a further example that clearly denotes the in-group and out-group:

'Gera (31.01.2017): Horde ausländischer Jugendlicher verprügelt in der Schule zwei 13-und 14-jährige deutsche Jungen' (Einzelfall-Map Gera)

'Gera: Horde of foreign youngsters beat two 13- and 14-year-old German boys at school' (authors' translation)

Another principle denotes that 'the people' and 'national communities' have 'unvarying characteristics', which have precedence over the individual.

Wien (18.01.2017): Muslima behauptet, eine Frau bätte sie vor eine einfahrende S-Babn gestoßen die Videoaufzeichnung entlarvt dies als Falschaussage’ (Einzelfall-Map Wien, 2017).

'Vienna: A Muslim woman claims that a woman would have pushed her in front of an incoming S-Bahn - the video recording unmasks this as a false statement' (authors' translation)

Is it necessary to quote her faith? Would it be the same headline if a Catholic woman had made a false statement? It is also interesting to note that the authors do not mention the faith of the 'alleged perpetrator' of the false allegation. The victim of the Muslim woman's false allegation is presented as neutral compared to the perpetrator of the allegation, who is only defined by her religion. In Zapata-Barrero \& Rubio-Carbonero's terminology (2014), a negative generalization ('a Muslim woman') is used. In addition, the information does not come from a reliable source - instead of being based on a police report or something 'certified', it comes from a newspaper article.

The third principle of Holzer's (1994) definition focuses on ethnocentrism and ethnopluralism. There is a strong desire for a 'world system of apartheid' - this vision would be 'Germany for Germans', 'Turkey for the Turks' and so on. This principle fulfils the same function of inclusion and exclusion as the racism theory of the 1930s. In this context, racism could be seen also as a supplement of 'radical nationalism'. 'Racism is constantly emerging out of nationalism. [...] And nationalism emerges out of racism. Classical nationalism often constructed the outsider in biological terms such as a "race", whereas today it has become more common to define the outsider in cultural and political terms' (Fuchs 2016:176). The principle is illustrated here:

Köln (25.01.2017): Drei 13 bis 17-jäbrige Südosteuropäer steigen in eine Wohnung ein und durchwühlen die Zimmer' (Einzelfall-Map Köln, 2017)

'Cologne: Three 13- to 17-year-old South-Eastern Europeans entered a flat and rifled through the rooms.' (authors' translation) 
Another example that fits into this category is the following account of an incident that took place in a supermarket:

Markdorf (17.01.2017): Bewaffneter Räuber mit osteuropäischem oder arabischen Akzent überfällt einen Einkaufsmarkt' (Einzelfall-Map Markdorf, 2017)

'Markdorf: Armed robber with Eastern-European or Arabic accent attacks a supermarket' (authors' translation)

Is it possible to identify an Eastern-European accent? Which language? Moreover, how readily can native German speakers distinguish this multiplicity from an Arabic accent? In this context, the question arises of whether the pronunciation of these languages is so similar that there could be a doubt as to which one was being spoken.

Summarized, the 'Einzelfall-Map' conveys a completely confused picture of the threatening 'other', a group comprising everyone who is not fair-skinned, blond and blue-eyed and tends not to speak accent-free German.

Another principle is the 'function of a scapegoat'. Groups such as 'the foreigners' are held responsible for social evils and other grievances: people look for a culprit who is 'responsible' for their own social and economic failures, which they project on to perceived enemy groups. And it seems that people have more confidence in conspiracy theories than in rational analysis.

Lindau (03.02.2017): Flüchtlinge werden bei Überprüfung des Sozialbetrugs erwischt, Asylantrag in Deutschland und Italien' (Einzelfall-Map Lindau, 2017)

'Lindau: Refugees are accused in a control of social fraud - application for asylum in Italy and Germany' (authors' translation)

In this case, the intention of the authors is to present refugees as culprits of social fraud, but where are the discussions of all the social fraud committed by Germans? This example can be linked with the 'topos of advantage', because social fraud offers asylum seekers greater access to benefits, which are denied to the 'normal' / 'honest' population (ZAPATA-Barrero \& Rubio-Carbonero, 2014).

A matching example was presented in Section 3, to give an idea of the surface of the map:

Cologne: raid in North African cultural café: theft, stolen goods, social fraud, drugs, misuse of documents'

If you follow the link, it becomes clear that the police questioned 60 people, of whom 4 had done something blameworthy. But if there was a raid in a German cultural café, for example a traditional one, and 60 people were questioned, the police would probably find more than 4 people who could be held on criminal charges. The main point is that it is less common to carry out raids in German cafés, because it seems to the police that customers of German cafés belong to a less criminal group than others (Belina 2010). Following Belina (2010), we can state that police practices and crime mapping say more about the police itself than about the social groups controlled.

'Nationalizing historiography' is the fifth principle of Holzer (1994). It takes place in the context of Germany and its history, for example. We still find an area of tension between 
guilt for and glorification of crimes committed in the name of 'the Germans' under the Nazi regime. This tension dissolves itself into trivialization and denial of the crimes committed.

'Cottbus: 5 Syrer fangen Streit mit vier Deutschen beim "Zug der fröblichen Leute” an - verletzen einen im Gesicht' (Einzelfall-Map 2017)

'Cottbus: 5 Syrians struggle with four Germans in the "procession of cheerful people" hurt one in the face' (authors' translation)

The 'procession of cheerful people' is a traditional German carnival event. The author's intention is probably to present the incident as a targeted attack on German culture. In the context of this example, it is also noteworthy that the police report indicated in the link is no longer available. Does this mean that the allegation was false?

The makers of the 'Einzelfall-Map' are quite honest in their description of the data used. In an interview about the criteria used for including cases in the map, one of the anonymous authors is quoted as saying:

'[We include cases] as soon as there are clear hints of foreign perpetrators. Either by explicit mention of nationality, or by description of the perpetrator by the police. I want to stress that we do not include Spanish, Italians, Netherlands or British people, but only those that are described as southerners by the police. That is, Turkish, Arabs, North Africans and Albanians. The information that the perpetrator "had black hair and wore a beard" is not enough for us [...]. We do not interpret; there has to be a clear hint denoting the origin of the perpetrator in the communication' (Krautkrämer, 2016).

In this context, we should refer to 'Übermedien', a platform with one basic objective: media criticism. The moderators of Übermedien investigated over 600 randomly selected 'marked occurrences' on the 'Einzelfall-Map' and got clear results: many of the incidents are unconfirmed or already refuted by the police, or even invented by the 'alleged victims', but still presented on the map (Übermedien 2017).

\section{Discussion: Right-wing language and spatialities}

For some years now, Volunteered Geographic Information has been used by a variety of social movements to further their own aims. The discussion of the 'Einzelfall-Map', however, shows that the spatial dimension derives not only from the visualization: the language used in these maps is also explicitly and implicitly spatial in a variety of ways.

The first point we want to make is how space and place interfere with the definitions of various groups shown as criminals by the map. If we look at HOLZER's (1994) definition of the syndrome approach as well as the semantic features of Zapata-Barrero \& RubioCarbonero (2014), we see that their main categories work with spatial entities that are spatially bound and also link characteristics of humans directly to their places of origin. These theoretical considerations can be clearly identified in many of the 'Einzelfall-Map' 'crimes'. The contributors here openly adhere to the bordering processes described by VAN Houtum \& van Naerssen (2002). Thus, we can clearly identify a spatial language before the map was even conceived. 
Another connection between right-wing language and spatiality is that the strategy of rightwing extremism is rooted in the concept of absolute space. For example, right-wing language links spatial (administrative or national) entities to collective character traits. This reification of character traits is typical of both an uninformed use of the spatial approach and of rightwing extremist arguments (Werlen, 1995). For educational purposes, we argue that it is this structural similarity that needs to be addressed, i.e. the similar reification on the basis of absolute concepts of space.

The second point, then, is the map itself. While it has been widely noted that maps are powerful visualizations that can only be read critically if we also look at the interests of the mapmaker (Harley, 1989; Wood, 1992; Gryl, 2009), we have probably not looked in sufficient detail at the language presented in the map's attribute data. This may be due partly to the classics of critical cartography having been written in an age of hard-copy maps, where this data was largely hidden. The VGI world of social geomedia allows for a more detailed analysis of the texts 'behind the map'. We have to accept that the power of maps is not limited, as has been naively suggested (Gryl \& Jekel, 2012), to furthering interests within the realm of human rights and (liberal) constitutions. Social geomedia are open and available to lay people of whatever persuasion, therefore requiring a new teaching methodology regarding critical online cartographies.

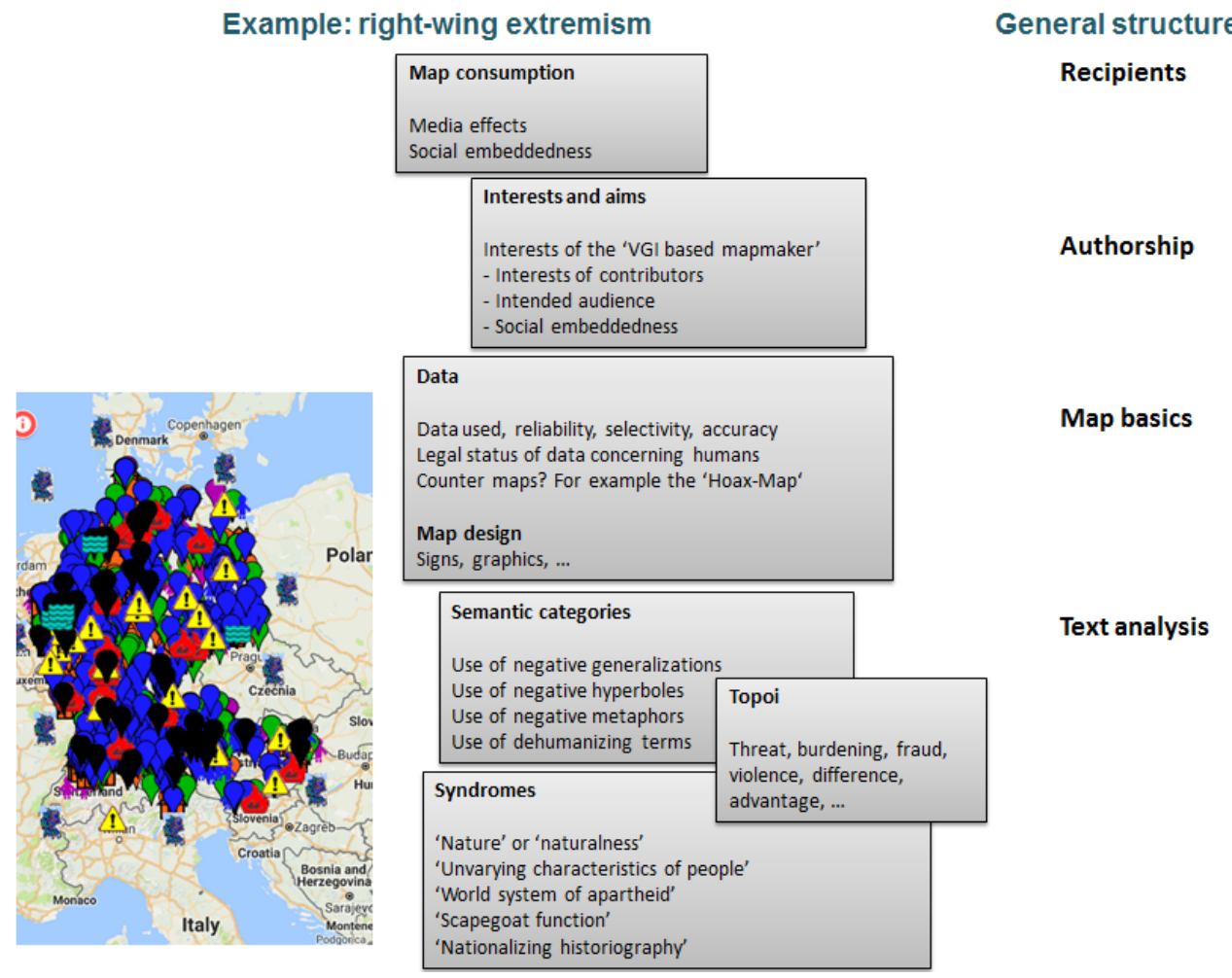

Figure 3: A suggested model for the deconstruction of VGI at secondary school: the example of rightwing geomedia production. 
Elaboration of the details of the model and its application in the classroom will be the subject of future work. However, for real-world school use, we wish to propose a model that looks in detail into these new developments of VGI and collaborative mapping (Figure 3). While this model includes a slightly simplified version of Gryl's (2009) critical map reading competence, we suggest that VGI now allows for substantially easier access to map construction and deconstruction through data provided by the contributors in texts, comments and hashtags (Reithmeier et al., 2016). This textual analysis of maps so far has not been used widely in secondary education.

The textual analysis here has to be related closely to the phenomena studied - in our case right-wing extremist maps. However, we suggest that the analysis of authorship, the consumer, map basics and text have to be adjusted according to the semantic categories, topoi and syndromes of the social phenomenon studied. The transfer of this deconstruction of maps to other discourses, for example sexism, therefore requires the inclusion of the semantic categories, topoi and syndromes relevant to the respective group. In simplifying the original conception of critical map reading, we hope to bring reflection on recent geomedia usage closer to both teachers' and students' everyday practice, while also providing an adequate methodology of textual analysis for school use.

\section{References}

Alvares, C. \& Dahlgren, P. (2016): Populism, extremism and media: Mapping an uncertain terrain. In: European Journal of Communication, Vol. 31(I), 46-57.

Belina, B. (2010): Crime Mapping. Production of ideology and alternatives. In: Jekel, T., Koller, A. \& Donert, K. (eds.): Learning with GI V. Heidelberg: Wichmann, 13-22.

Der Standard (2017): "Einzelfall"-Karte über "kriminelle Ausländer" voller Fehler. Online version: http://derstandard.at/2000050835111/Einzelfall-Karte-ueber-kriminelle-Auslaender-vollerFehler, 19.06.2017.

Einzelfall-Map, 2016. https://www.google.com/maps/d/viewer?mid=1_rNT3k2ZXB-f9z2nSFMIBQKXCs\&hl=en_US\&ll=60.6325623185327\%2C20.043452102246192\&z=6, 19.06.2017.

Elwood, S. \& Mitchell, K. (2013): Another Politics is Possible: Neogeographies, Visual Spatial Tactics and Political Formation. In: Cartographica 48, 4, 275-292.

Fine Dictionary: Term 'Horde'. http:/ /www.finedictionary.com/horde.html, 15.06.2017.

Fuchs, C. (2016): Racism, Nationalism and Right-Wing Extremism Online: The Austrian Presidential Election 2016 on Facebook. In: Momentum-Quarterly - Zeitschrift für Sozialen Fortschritt, Vol. 5, No. 4, 200-264.

Gordon, E., Elwood, S. \& Mitchell, K. (2016): Critical Spatial Learning: Participatory Mapping, Spatial Histories, and Youth Civic Engagement. In: Children's Geographies, 558-572 doi: 10.1080/14733285.2015.1136736.

Gryl, I. (2009): Kartenlesekompetenz. Ein Beitrag zum konstruktivistischen Geographie-unterricht (= Materialien zur Didaktik der Geographie- und Wirtschaftskunde 22), Wien.

Gryl, I. \& Jekel, T. (2012): Re-centering geoinformation in secondary education. Toward a spatial citizenship approach. In: Cartographica 47, 1, 18-28.

Harley, J.B. (1989): Deconstructing the map. In: Cartographica 26 (2), 1-20. HoLzER, W. (1994):

Rechtsextremismus. Konturen, Definitionsmerkmale und Erklärungsansätze. In:

Dokumentationsarchiv des österreichischen Widerstandes (Hrsg.): Handbuch des österreichischen Rechtsextremismus. Wien, 12-96. 
Holzer, W. (1994): Rechtsextremismus. Konturen, Defi nitionsmerkmale und Erklärungsansätze. In: Dokumentationsarchiv des österreichischen Widerstandes (Hrsg.):

Handbuch des österreichischen Rechtsextremismus. Wien: Deuticke, 12-96.

van Houtum, H. \& van Naerssen, T. (2002): Bordering, Ordering and Othering. In: Tjidschrift voor Economische en Sociale Geografie, Vol. 93, No. 2, 125-136.

Jekel, T. \& Huber, F. (2005): Barockes Salzburg: Zur Normalisierung von Raumkonstruktionen. In: Flitner, M. \& Lossau, J.: Themenorte. Produktion und Durchsetzung von Raumbildern. Münster: Lit, 91-106.

Jekel, T., Lehner, M. \& Vogler R. (2017): „,.. das sind doch nur Lausbubenstreiche“. Geographiedidaktische Zugänge zum Umgang mit rechtsextremen Symbolen im öffentlichen Raum. In: GW-Unterricht, 146, 5-18.

Krautkrämer, F. (2016): "Es macht mich wütend”. In: Junge Freiheit. https://jungefreiheit.de/debatte/interview/2016/es-macht-mich-wuetend/, 01.02.2017

Pelinka, A. (2013): Right-Wing Populism: concept and typology. In: Wodak,R., KhosraviNik, M. \& Mral, B.: Right-Wing Populism in Europe. Politics and Discourse. London, New York, 3-22.

Pokraka, J.; Könen, D., Gryl, I. \& Jekel, T. (2016): Raum und Gesellschaft: Spatial Citizenship als Integration von Medien-, geographischer und politischer Bildung. In: Kuckuck, M., \& Budke, A. (eds): Politische Bildung im Geographieunterricht. Stuttgart, 77-87.

Rapp, C. \& Wagner, T. (2012): On Some Aristotelian Sources of Modern Argumentation Theory, Online version: http://link.springer.com/article/10.1007/s10503-012-9280-9, 01.02.2017.

Reithmaier, C., Buschbaum, K., Blitz, A. \& Kanwischer, D. (2016), "Heaven. \#shopping \#Frankfurt \#weekend \#joy. Hashtags, Constructions of Space, Geography Education. GI_Forum 5, 1, 282294.

Statista (2016). Anzahl der Asylanträge in Deutschland nach Bundesländern im Jahr 2017. https://de.statista.com/statistik/daten/studie/451902/umfrage/asylantraege-in-deutschlandnach-bundeslaendern/, 19.06.2017.

Übermedien (2017): Kartenlegen mit kriminellen Ausländern. http://uebermedien.de/11488/kartenlegen-mit-kriminellen-auslaendern/, 19.06.2017

Werlen, B. (1995): Sozialgeographie alltäglicher Regionalisierungen. Band 1: Zur Ontologie von Gesellschaft und Raum. Stuttgart (=Erdkundliches Wissen, 89).

Wodak, R. (2013): ‘Anything Goes!' - The Haiderization of Europe. In: Wodak,R., KhosraviNik, M. \& MrAL, B.: Right-Wing Populism in Europe. Politics and Discourse. London, New York, 23-37.

Wood, D. (1992): The Power of Maps. London: Routledge.

Zapata-Barrero, R. \& Rubio-Carbonero, G. (2014): Monitoring xenophobic political discourses: a pilot study in Catalonia, Barcelona. 